\title{
Momordica Janarthanamii (Cucurbitaceae); A Remarkable New Species From Northern Western Ghats, India
}

Kumar Vinod C. Gosavi ( $\nabla$ kumarvinodgosavi@gmail.com )

HPT Arts and RYK Science College https://orcid.org/0000-0001-6681-2253

Avinash R. Gholave

Vasantrao Naik Arts Science \&amp; Commerce College

Nilesh A. Madhav

HPT Arts and RYK Science College

Sharad S. Kambale

M.V.P. Samaj's Arts, Commerce \&amp; Science College

\section{Short Report}

Keywords: Cucurbitaceae, Dioecious species, India, Momordica, Spine gourd, Taxonomy, Vegetable

Posted Date: March 13th, 2021

DOI: https://doi.org/10.21203/rs.3.rs-306676/v1

License: (c) (i) This work is licensed under a Creative Commons Attribution 4.0 International License. Read Full License 


\section{Abstract}

Momordica janarthanamii, a new species L., is described and illustrated from northern Western Ghats, India. The new species is closely related to Momordica dioica Roxb. ex Willd. Colored photographs, economical value, ecological note and distribution of the new species are provided. A key for the dioecious species of Momordica from India has also been provided to facilitate identification.

\section{Introduction}

Momordica L. is one of the largest genera of the Cucurbitaceae and distributed throughout tropics of the old world (Mabberley 2017). Schaefer and Renner (2010) reported 59 species while Mabberley (2017) reported 45 species in the genus. In Asia, Momordica is represented by 12 taxa, among them 6 species, one subspecies and one variety are reported from India (Bharathi and Joseph 2013).

Momordica is diversified by having annual to tuberous perennial and monoecious to dioecious in habit. Phylogenetically monoecious group of the genus has evolved from dioecious species (Schaefer and Renner 2010). Recently karyomorphological and molecular work of Indian Momordica carried out by Ghosh et al. (2020). Many species of the genus are well known for their use as fruit vegetable; however, only Momordicacharantia L. is widely cultivated for its edible and medicinal properties. In India, along with wild occurrence almost all 8 taxa are locally cultivated.

During plant exploration of the northern Western Ghats of Maharashtra, authors had collected an interesting dioecious species of Momordica. The species is remarkable because of its orbicular conspicuous bracts of male flowers. After perusal of literature (Trimen 1894; Cook 1903; Gamble 1935; Chakravarty 1982; de Wilde and Duyfjes 2002, Joseph and Antony 2007, 2010; Bharathi and Joseph 2013) it was found that, species is closely related to Momordica dioica Roxb. ex Willd., which is distributed in Bangladesh, India, Pakistan and Sri Lanka but differs in many remarkable characters (Table.1). After examination of a type specimen of Momordicadioica (660 597 housed in BR) and aforesaid literature including protologue of M.dioica (Willdenow 1805) it is confirmed that, it's an interesting undescribed species of the genus Momordica. Therefore, it is described and illustrated here as a Momordicajanarthanamii Gosavi, Gholave Madhav \& Kambale.

\section{Materials And Methods}

The specimens of Momordica were collected from Karanjali ghat (Kumbharbari), Nashik in July 2020. The morphological characters were studied under Leica EZ4 Stereo Zoom microscope. Diagnostic characters of the unknown species were compared with protologue and type specimens of its closely related species i.e. M. dioica. Photographs in the field and different parts of the plants were taken by using M50 Canon camera. The Type specimens have been deposited at BSI, CAL and SUK herbaria.

\section{Results}




\section{Taxonomy}

Momordicajanarthanamii Gosavi, Gholave, Madhav \& Kambale, sp. nov. Type: INDIA, Maharashtra, Nashik District, Karanjali Ghat (Kumbharbari), 20¹5'37.04"N, 73³6'58.28"'E, 646 m, 07 July 2020, K. V.C. Gosavi \& A.R. Gholave 5141 (holotype CAL!, isotypes BSI!, SUK!) (Figs. 1, 2, 3, 4).

\section{Diagnosis}

Momordicajanarthanamii is closely related to $M$. dioica but differs in buds of male flowers not subtended in bract (vs. subtended in bract), bracts of male flowers orbicular, $0.4-0.5 \mathrm{~cm}$ long, not covers pedicel and glandular along margins (vs. reniform, cucullate, up to $1 \mathrm{~cm}$ long, covers pedicel and eglandular along margins), bracts of female flowers ovate and glandular along margins (vs. cucullate and eglandular), sepals of female flowers 10-12 mm long, linear elliptic to ensiform, glandular along margins and acute at apex (vs. 3-6 mm long, elliptic to oblong, eglandular along margins and mucronulate at apex), seeds hexagonal in shape and 7-9 mm long (vs. round to slightly ovoid in shape and 2-3 mm across).

Perennial, dioecious, tuberous, tendrillar climbers, up to $10 \mathrm{~m}$ high. Tubers elongated or irregularly bulged at maturity. Stems pentangular, inter-nodes $5-15 \mathrm{~cm}$ long, minutely hirsute, nodes pilose to villous at either side of leaf base or base of branches. Tendrils simple, $5-17 \mathrm{~cm}$ long, basal $2-5 \mathrm{~cm}$ long part uncoiled, upper 3-12 cm long part coiled. Petioles $2-9 \mathrm{~cm} \times 1.5-4 \mathrm{~mm}$, villous at the apical region, channeled, channel ribs sparsely scaberulous to glabrous. Lamina ovate to broadly triangular in outline, rarely hastate, entire or 3-5 lobed, $6-13 \times 5-15 \mathrm{~cm}$, base cordate, apex acute or acuminate, margin undulate or crenulate to coarsely denticulate, scabrous, lateral veins 3 paired; lower vein pair inconspicuous, short, running near to basal margin, upper 2 pairs fused at base, secondary and tertiary veinlets form denticulate or mucronulate at the end of margin, bulbous based short hairs scattered on upper surface, cystoliths on lower surface, veins of lower surface sparsely hirsute to pilose. Male flower solitary to 5-8 in scorpioid cymes; male flowers 5-9 $\times 4-6 \mathrm{~cm}$, axillary; solitary flower pedicel $4.5-8 \mathrm{~cm}$ $\times 1.5-2 \mathrm{~mm}$ long, thick, angled, articulated above the bract, hirsute to pilose. Nodal bracts on cyme, lower 0-3 sterile, margins glandular to eglandular, acute to acuminate at apex. Bracts at the tip of pedicel, orbicular, 4-5 $\times 5-6 \mathrm{~mm}$, persistent, margins covered with glands, pilose at apical margin, apex dark green, thick, acute, ca. 10 nerved, lower surface pilose hairy. Receptacle tube funnel shape, $0.8-1 \times 0.4-$ $0.5 \mathrm{~cm}$, purplish black, echinate to pilose or mixed. Sepals 5 , free, $0.8-1 \times 0.2-0.4 \mathrm{~cm}$, elliptic-oblong, yellowish purple at base, greenish yellow at apex, margins ciliate to short pilose, sparsely 5 -nerved, acute at apex, both surfaces sparsely hairy. Petals 5 , free, obovate, $3-4 \times 2.3-3 \mathrm{~cm}$, bright yellow, veins prominent, villous to pubescent on outer surface. Stamens 3 , two with a pair of anthers, one with a single anther; filaments whitish yellow 3-4 mm long, glabrous or sparsely hairy; anthers $2-3 \times 1.5-2 \mathrm{~mm}$, extrorse, thecae dull black, S-shaped. Female flowers 5-10 × 4-7.5 cm, solitary, in the leaf axils; pedicel $3.5-8 \mathrm{~cm} \times 1.5-2 \mathrm{~mm}$, angled, hirsute to pilose. Bracts at middle of pedicel, $1.0-2.0 \times 0.8-1.5 \mathrm{~mm}$, persistent, ovate, greenish white, few glands at margins, sparsely hairy, apex acute, dark green. Sepals 5 , free, 10-12 × 1.5-2 mm, linear elliptic to ensiform, green, margins sparsely hairy, few glands on margins, sparsely 5-nerved, acute at apex, with dark green tip. Petals 5, free, ovate, $3-5 \times 2.2-4 \mathrm{~cm}$, bright yellow, 
veins prominent, villous to pubescent on outer surface. Ovary ovoid, $1-1.5 \times 0.4-0.6 \mathrm{~cm}$, densely covered with ca. $1 \mathrm{~mm}$ long soft papillae. styles 3-5 mm long, whitish green, stigma $4 \times 8 \mathrm{~mm}, 3$ lobed, each lobe bifid. Fruits broadly ellipsoid to ovoid, or with round base and rostrate apex, 3.5-6 $\times 2-3 \mathrm{~cm}$, dark green to whitish green, turning bright orange on ripening, densely covered with spines; spines soft, $2-3 \mathrm{~mm}$ long, terete or slightly compressed. Pulp sweet when ripe, carmine red. Seeds black, shining, losing its lustre on drying, hexagonal shaped, sculptured on faces with irregular blotches of furrows and ridges, 7$9 \times 5-6.5 \mathrm{~mm}$, seed coat hard, brittle; endosperm oily, aromatic.

Phenology: Flowering and fruiting - July to August.

Distribution: India: Maharashtra: Nashik district.

Local name: Kartule (Marathi).

Specimens examined: INDIA, Maharashtra, Nashik Districts, Karanjali Ghat (Kumbharbari), 20¹5'37.04"N, $73^{\circ} 36^{\prime} 58.28^{\prime \prime \prime} \mathrm{E}, 646 \mathrm{~m}, 07$ July 2020, K.V.C. Gosavi \& A.R. Gholave 5141 (male) (holotype CAL!, isotypes BSI!, SUK!).

Additional specimens examined: INDIA, Maharashtra, Nashik Districts, Karanjali Ghat, 07 July 2020, K.V.C. Gosavi \& A.R. Gholave 5142 (female); 20 July 2020, K.V.C. Gosavi \& N.A. Madhav 5151 (male); 20 July 2020, K.V.C. Gosavi \& N.A. Madhav 5152 (female); Tryambakeshwar, Vatvad, 19 July 2020, S.S. Kambale \& A.R. Gholave ARG-1001 (male) (housed in BSI).

Economic value: Fruits of the species are used as vegetable by localites. The unripe fruits are also sold in local markets.

Ecological note:Momordicajanarthanamii is commonly grows from foothills to almost top of Karanjali ghat and also at hills of Tryambakeshwar in Nashik districts. Thus, there is need to explore the species to estimate its IUCN status. At present it is considered here as Data Deficient (DD, IUCN, 2019). The species is commonly found on shrubby species and bushes like Carissacarandas L., Strobilanthescallosa (Nees) Bremek, Capparissepiaria L., Lantanacamara L. and Tectonagrandis L.f.

Etymology: The specific epithet is in honor of Prof. Malapati Kuppuswamy Janarthanam, Department of Botany, Goa University for his valuable voluminous contribution in the field of angiosperm taxonomy and conservation of the rare and endemic species of Western Ghats, India.

\section{Discussion And Conclusion}

Presently, Momordica is represented by seven species, one subspecies and one variety in India. The new species described herein can also be utilized as a new crop. After screening for its nutritious properties and food value it will be useful in the breeding programmes to improve the cultivated species of Momordica. 
Key to the dioecious species of Indian Momordica

1a. Inner 3 petals with black purple blotch

1b. Petals of flower without any black purple blotch

3

2a. Leaf margins dentate; petioles eglandular

M. subangulata

subsp. renigera

2b. Leaf margins undulate; petioles gland dotted

M. cochinchinensis

3a. Buds of male flower subtended in bract; bracts of male flowers reniform, cucullate; swollen, covers pedicel

3b. Buds of male flowers not subtended in bract; bracts of male

flowers orbicular; not covers pedicel

M. janarthanamii

4a. Sepals in male flowers blackish purple, broad,

round or scarious at apex

M. sahyadrica

4b. Sepals in male flowers whitish yellow, mucronulate at apex

M. dioica

\section{Declarations}

Acknowledgements Authors are thankful to BR herbarium for providing type images of the M. dioica; to the Principals and Heads, of respective institutes for laboratory facilities. KVCG and NAM are thankful to SERB-DST Government of India (project under the scheme of Core Research Grant; File No. CRG/2018/00I381) for financial assistance.

Funding: NA

Conflicts of interest/Competing interests: The authors declare that they have no conflict of interest Availability of data and material: Type of the new species will be submitted in the mentioned herbaria after published manuscript.

Code availability NA

Authors' contributions KVCG: Collected type and extra specimens, identified and taken photographs of new species, wrote manuscript and prepared type specimens. ARG: Collected type and extra specimens, 
identified and taken photographs of new species, reviewed the manuscript. NAM: Drawn illustration, collected and prepared extra specimens. SSK: Identified, analysed characters with protologue and type specimens of allied species, reviewed the manuscript.

Ethics approval: NA

Consent to participate: NA

Consent for publication: NA

\section{References}

1. Bharathi LK, Joseph JK (2013) Momordica genus in Asia: An overview Springer, New Delhi, Heidelberg, New York, Dordrecht, London doi 10.1007/978-81-322-1032-0

2. Chakravarty HL (1982) Fascicles of Flora of India, Fascicle II, Cucurbitaceae, Botanical survey of India, Howrah Clarke CB (1879) Cucurbitaceae. In: Hooker JD (ed) Flora of British India, vol-2, Reeve, London, pp 604-635

3. Cooke T (1903) The Flora of the Presidency of Bombay, vol-1, Taylor and Francis, London, pp 524547

4. Gamble JS, Fischer CEC (1935) Flora of the presidency of Madras, Vol-1, Adlard and Son limited, London, $1935 \mathrm{pp}$

5. $526-543$

6. Ghosh I, Saha PS, Bhowmick BK, Jha S (2020) A phylogenetic analysis of Momordica (Cucurbitaceae) in India based on karyo-morphology, nuclear DNA content and rDNA ITS1-5.8SITS2 sequences. Protoplasma doi: https://doi.org/10.1007/s00709-020-01576-z

7. IUCN (2017) IUCN Red List Categories and Criteria: Version 3.1, 2nd ed., IUCN, Species Survival Commission, Gland. https://www.iucnredlist.org/.

8. Joseph JK, Antony VT (2007) Momordicasahyadrica sp.nov. (Cucurbitaceae), an endemic species of Western Ghats of India. Nord J Bot 24:539-542

9. Joseph JK, Antony VT (2010) A taxonomic revision of the genus Momordica L. (Cucurbitaceae) in India. Indian J Plant Genet Resour 23:172-184 doi:10.1007/978-81-322-1032-0

10. Mabberley DJ (2017) The plant-book: a portable dictionary of the vascular plants. Cambridge University Press, Cambridge

11. Schaefer H, Renner SS (2010) A three-genome phylogeny of Momordica (Cucurbitaceae) suggests seven returns from dioecy to monoecy and recent longdistance dispersal to Asia. Mol Phylo genet Evol 54:553-560 doi: 10.1016/j.ympev.2009.08.006

12. Trimen H (1894) A hand book of Flora of Ceylon, part-II, Dulau \& Co, London, pp 242-262

13. de Wilde WJJO, Duyfjes BEE (2002) Synopsis of Momordica (Cucurbitaceae) in SE-Asia and Malesia. Bot Z 87 (3):132-148 
14. Willdenow CL (1805) Linnaei species plantarum, vol 4., GC Nauk, Berolini, Vienna, pp 601-605

\section{Tables}

Table 1. Comparison of diagnostic characters between Momordica dioica Roxb. ex Willd. and $M$. janarthanamii sp. nov.

\begin{tabular}{|llll|}
\hline $\begin{array}{l}\text { Sr. } \\
\text { no. }\end{array}$ & Characters & M. dioica & M. janarthanamii \\
\hline 1 & $\begin{array}{l}\text { Inflorescence } \\
\text { of male } \\
\text { Flowers }\end{array}$ & $\begin{array}{l}\text { Solitary or a loose fascicle with 5-7 } \\
\text { (15) flowers }\end{array}$ & $\begin{array}{l}\text { Solitary and scorpioid cyme with 5-8 } \\
\text { flowers }\end{array}$ \\
\hline 2 & $\begin{array}{l}\text { Buds of } \\
\text { male flowers }\end{array}$ & Subtended in bract & Not subtended in bract \\
\hline 3 & $\begin{array}{l}\text { Bracts of } \\
\text { male flowers }\end{array}$ & $\begin{array}{l}\text { Reniform, cucullate; up to 1 cm long; } \\
\text { covers pedicel; eglandular along } \\
\text { margins }\end{array}$ & $\begin{array}{l}\text { Orbicular; } 0.4-0.5 \text { cm long; not covers } \\
\text { pedicel; glandular along margins }\end{array}$ \\
\hline 4 & $\begin{array}{l}\text { Bracts of } \\
\text { female } \\
\text { flowers }\end{array}$ & $\begin{array}{l}\text { Cucullate; eglandular } \\
\text { Ovate; glandular along margins }\end{array}$ \\
\hline 5 & $\begin{array}{l}\text { Sepals of } \\
\text { female } \\
\text { flowers }\end{array}$ & $\begin{array}{l}\text { 3-6 mm long; elliptic to oblong; } \\
\text { eglandular along margins; } \\
\text { mucronulate at apex }\end{array}$ & $\begin{array}{l}\text { 10-12 mm long; linear elliptic to } \\
\text { ensiform; glandular along margins; } \\
\text { acute at apex }\end{array}$ \\
\hline 6 & $\begin{array}{l}\text { Seeds } \\
\text { round to slightly ovoid in shape; 2-3 } \\
\text { mm across }\end{array}$ & Hexagonal in shape; 7-9 $\times$ 5-6.5 mm \\
\hline
\end{tabular}

\section{Figures}



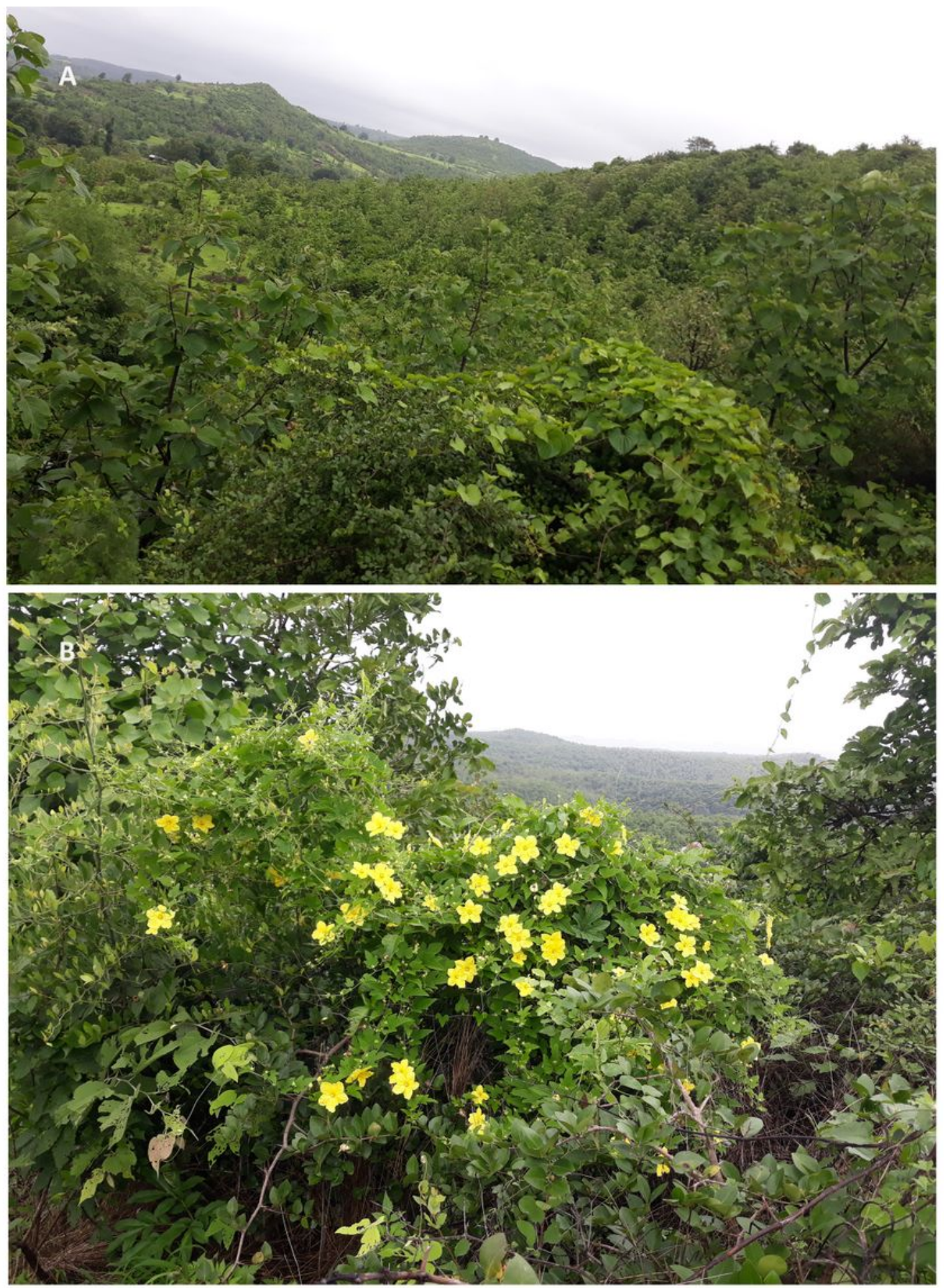

\section{Figure 1}

Momordica janarthanamii sp. nov.: A. habitat, B. male plant. Photographs by K.V.C. Gosavi and A.R. Gholave 


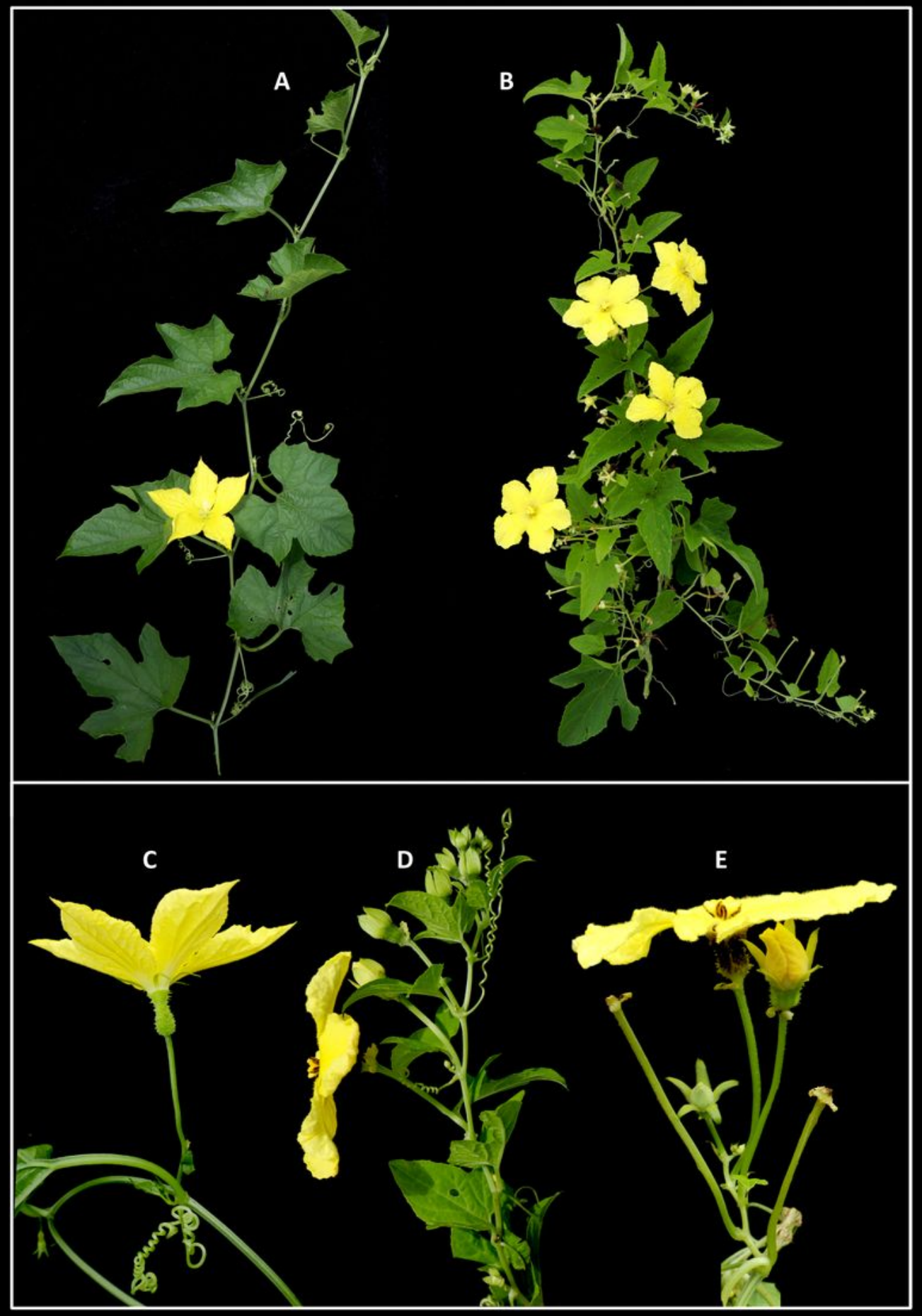

\section{Figure 2}

Momordica janarthanamii sp. nov.: A. flowering twig of female plant, B. flowering twig of male plant, C. solitary flower in female plant, D. solitary flower in male plant, E. scorpioid cyme in male plant. Photographs by K.V.C. Gosavi 

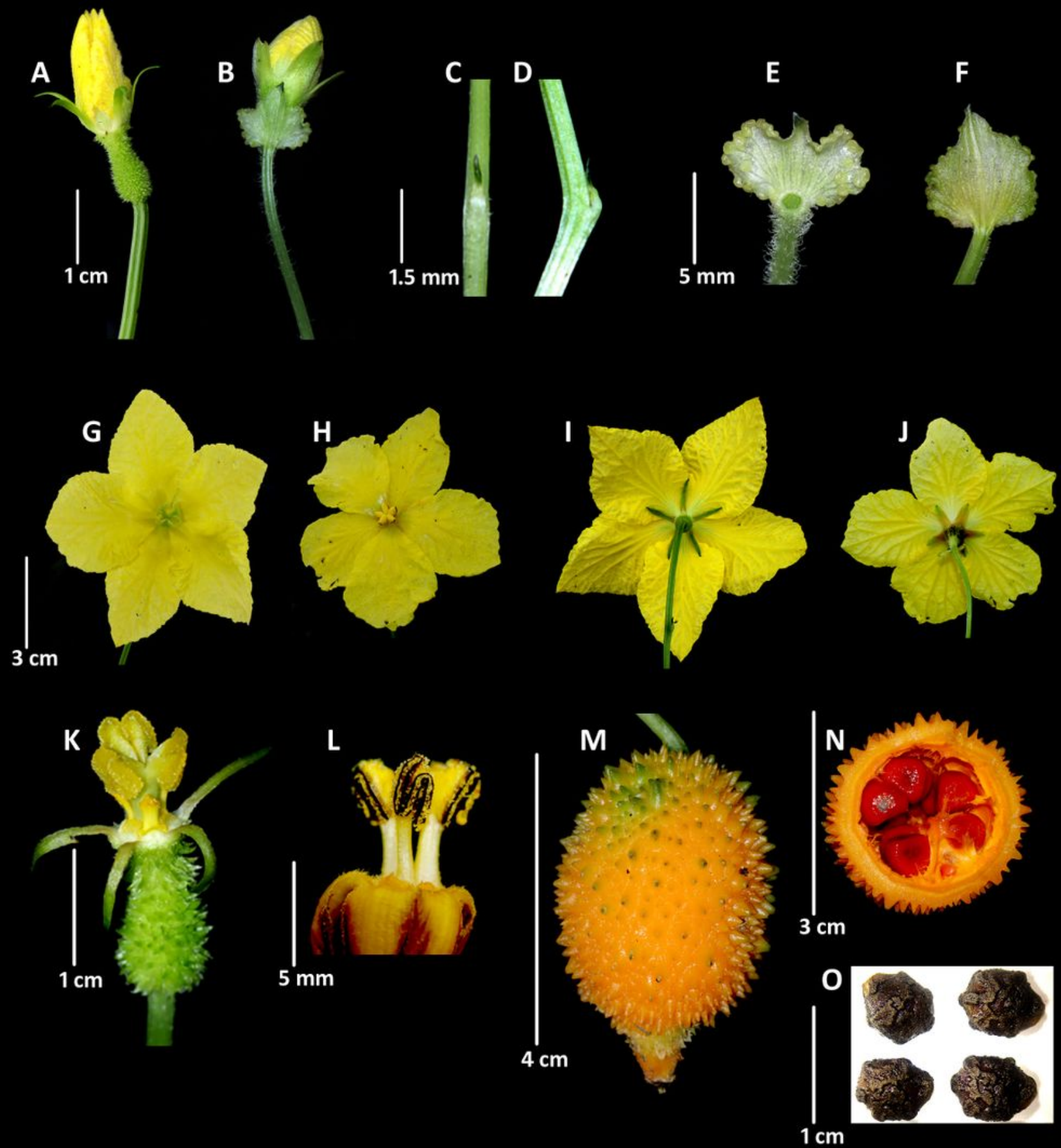

\section{Figure 3}

Momordica janarthanamii sp. nov.: Female plant: A. flower bud, C \& D. bract, G. top view of flower, I. lower view of flower showing calyx, K. gynoecium showing stigma, style and ovary, M. fruit, N. TS of fruit, $\mathrm{O}$. seeds. Male plant: B. bud, E \& F. bracts, H. top view of flower, J. lower view of flower showing calyx, L. stamens. Photographs by K.V.C. Gosavi 


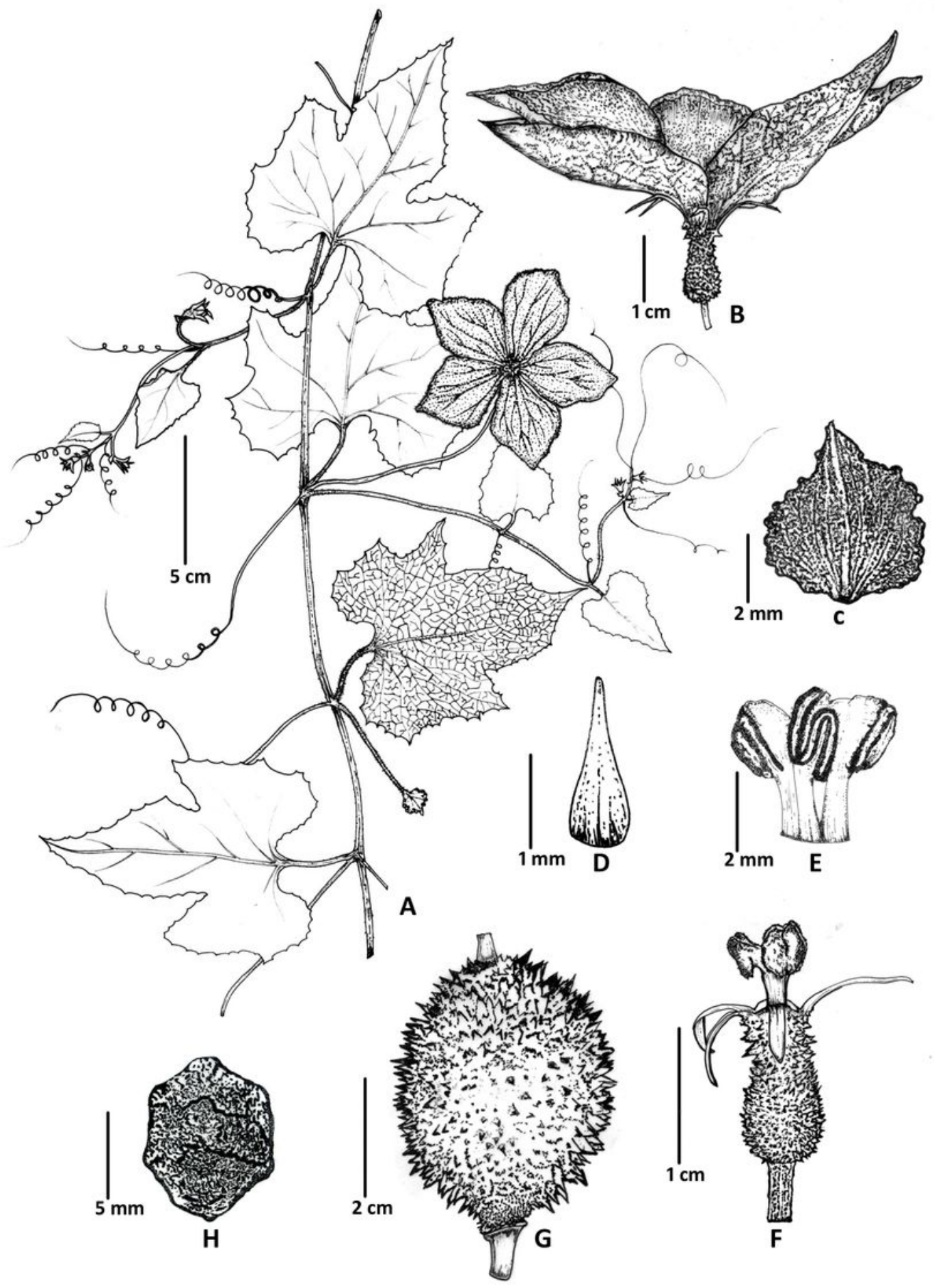

Figure 4

Momordica janarthanamii sp. nov.: A. flowering twig of male plant, B. flower of female plant, C. bract of male flower, D. bract of female flower, E. stamens, F. gynoecium, G. fruit, H. Seed. Drawn from K.V.C. Gosavi \& A.R. Gholave 5141 and 5142 by N.A. Madhav 